\title{
Phytocenosis biodiversity at various water levels in mesotrophic Lake Arakhley, Lake Baikal basin, Russia
}

\author{
Gazhit T Tsybekmitova ${ }^{\text {Corresp., } 1}$, Larisa D Radnaeva ${ }^{2}$, Natalya Tashlykova ${ }^{\text {Corresp., }}{ }^{1}$, Valentina Shiretorova ${ }^{2}$, Balgit B. \\ Bazarova $^{1}$, Arnold Tulokhonov ${ }^{2}$, Marina O Matveeva ${ }^{1}$ \\ 1 Laboratory of Aquatic Ecosystem, Institute of Natural Resources, Ecology and Cryology of the Siberian Branch of the Russian Academy of Sciences, \\ Chita, Zabaykalskii krai, Russian Federation \\ 2 Laboratory of Chemistry of Natural Systems, Baikal Institute of Nature Management of the Siberian Branch of the Russian Academy of Sciences, Ulan- \\ Ude, Buryatia, Russian Federation \\ Corresponding Authors: Gazhit T Tsybekmitova, Natalya Tashlykova \\ Email address: gazhit@bk.ru, NatTash2005@yandex.ru
}

Small lakes have lower water levels during dry years as was the case in 2000-2020. We sought to show the biodiversity of plant communities at various water levels in Lake Arakhley. Changes in moisture content are reflected in the cyclical variations of the water level in the lake, which decreased approximately $2 \mathrm{~m}$ in 2017-2018. These variations affect the biological diversity of the aquatic ecosystems. We present the latest data on the state of the plant communities in this mesotrophic lake located in the drainage basin of Lake Baikal. Lake Arakhley is a freshwater lake with low mineral content and a sodium hydrocarbonate chemical composition. Changes in the nutrient concentration were related to precipitation; inflow volume and organic matter were autochtonous at low water levels. The most diverse groups of phytoplankton found in the lake were Bacillariophyta, Chlorophyta, and Chrysophyta. High biodiversity values indicate the complexity and richness of the lake's phytoplankton community. A prevalence of Lindavia comta was observed when water levels were low and Asterionella formosa dominated in high-water years. The maximum growth depth of lacustrine vegetation decreased from $11.0 \mathrm{~m}$ to 4.0 $\mathrm{m}$ from 1967 to 2018. Decreasing water levels were accompanied by a reduction in the littoral zone, altering the communities of aquatic plants. The hydrophyte communities were monodominant in the dry years and were represented by Ceratophyllum demersum. The vegetation cover of the lake was more diverse in high-water years and variations in the lake's water content altered the composition of biogenic substances. These changes were reflected in the lake's phytocenosis. 


\section{Phytocenosis biodiversity at various water levels in mesotrophic Lake Arakhley, Lake Baikal basin, Russia}

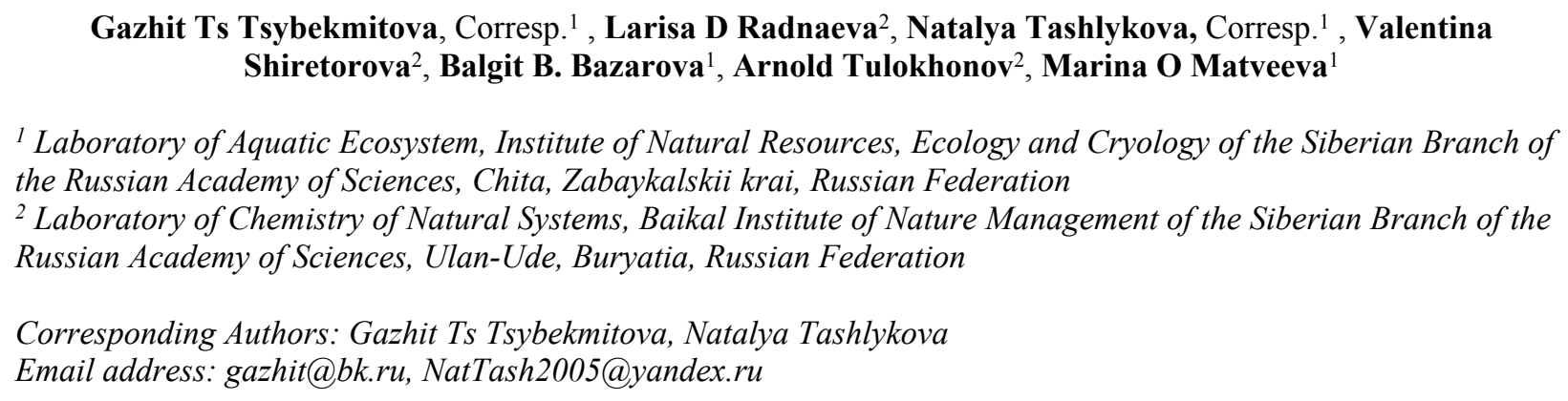

Abstract: Small lakes have lower water levels during dry years as was the case in 2000-2020. We sought to show the biodiversity of plant communities at various water levels in Lake Arakhley. Changes in moisture content are reflected in the cyclical variations of the water level in the lake, which decreased approximately $2 \mathrm{~m}$ in 2017-2018. These variations affect the biological diversity of the aquatic ecosystems. We present the latest data on the state of the plant communities in this mesotrophic lake located in the drainage basin of Lake Baikal. Lake Arakhley is a freshwater lake with low mineral content and a sodium hydrocarbonate chemical composition. Changes in the nutrient concentration were related to precipitation; inflow volume and organic matter were autochtonous at low water levels.

The most diverse groups of phytoplankton found in the lake were Bacillariophyta, Chlorophyta, and Chrysophyta. High biodiversity values indicate the complexity and richness of the lake's phytoplankton community. A prevalence of Lindavia comta was observed when water levels were low and Asterionella formosa dominated in high-water years. The maximum growth depth of lacustrine vegetation decreased from $11.0 \mathrm{~m}$ to $4.0 \mathrm{~m}$ from 1967 to 2018 . Decreasing water levels were accompanied by a reduction in the littoral zone, altering the communities of aquatic plants. The hydrophyte communities were monodominant in the dry years and were represented by Ceratophyllum demersum. The vegetation cover of the lake was more diverse in high-water years and variations in the lake's water content altered the composition of biogenic substances. These changes were reflected in the lake's phytocenosis.

\section{Introduction}

The global nature of climate change has been widely discussed (Koch, 2001; Riis \& Hawes, 2002; Bornette \& Puijalon, 2011; Ji et al., 2014; Donchyts et al., 2016; Huang et al., 
2016) and climatic changes can be detected at the regional level when we examine environmental factors such as level of the water surface, the mode of its fluctuations and the temperature of the atmospheric air (Hill et al., 1998; Obyazov et al., 2002; Obyazov, 2011; Kuang \& Jiao, 2016; Yang et al., 2016).

The ecological effects of climate change are most evident in primary aquatic production processes (Paerl et al., 2003). The filling and evaporation of lakes due to climatic fluctuations indirectly regulates the growth and development of plant communities (Bornette \& Puijalon, 2011). Phytoplankton dynamics are closely related to annual fluctuations in temperature and water levels, the mixing of the water column, and the availability of nutrient resources and their consumption (Winder \& Sommer, 2012). Phytoplankton structure, seasonal dynamics, and taxonomic composition are directly or indirectly affected by these environmental factors due to climate changes (Winder \& Sommer, 2012; Liu et al., 2015; Izaguirre et al., 2015). These factors influence various physiological processes, causing a shift in the timing and extent of plankton algal blooms and favor the development of species that are most adapted to changing climatic conditions (Nöges et al., 2003; Adrian et al., 2006; Lewandowska \& Sommer, 2010; Zohary et al., 2020).

Recent studies have focused on the relationship between the structural characteristics of phytoplankton and environmental factors (Bierman \& Dolan, 1981; Watson et al., 1997; Nalewajko \& Murphy, 2001; Tian et al., 2013; Chang et al., 2013; Wang et al., 2015). These studies focus on the factors with the greatest impact on phytoplankton communities. According to this research, the structural characteristics of phytoplankton are regulated by temperature, illumination, nutrients, and water level (Yang et al., 2016; Yang et al., 2017).

Macrophytes are reliable indicators of long-term changes in the littoral zone, but they do not reflect rapid changes in water quality (Palmer et al., 1992; Melzer, 1999). Macrophytic thickets are the main trophic community and are a natural biofilter for substances entering the ecosystem. Recent studies have found decreasing aquatic vegetation in approximately $65.2 \%$ of the world's lakes (Zhang et al., 2017).

It is important to monitor and analyze water ecosystems to improve our awareness of the possible negative biological effects caused by climate changes and to regulate anthropogenic activities. Research on the biological diversity of the organizational levels and dynamics in 
68

69

70

71

72

73

74

75

76

aquatic ecosystems to the north of Central Asia may contribute to the understanding of biosphere balance, especially in water ecosystems.

The purpose of this study is to assess the biodiversity of plant communities under changing water levels in Lake Arakhley.

\section{Materials and Methods}

\subsection{Study Area}

Lake Arakhley is located south of the Vitim Plateau within the Beklemishev tectonic basin. The area is characterized by a continental subarctic climate with considerate diurnal temperatures, long, cold, dry winters and short, hot summers with more precipitation occurring during the latter half of the season. The lake is used for recreation and fishery purposes and is approximately $100 \mathrm{~km}$ from Chita, the capital of the Zabaikalsky region (Figure 1, Table 1).

Lake Arakhley's water regime is determined by changes in the ratio of water balance elements. Precipitation on the reservoir surface is slightly higher than the inflow (precipitation equals 17.8 million $\mathrm{m}^{3} /$ year; inflow equals 16.1 million $\mathrm{m}^{3} /$ year) and accounts for the incoming water balance of Lake Arakhley. Water typically dissipates through evaporation (27.1 million $\mathrm{m}^{3} /$ year) and runoff from the lake only accounts for $20 \%$ of the outflow (Obyazov, 2011). Consequently, changes in the moisture content are reflected in the cyclical variations in the water level. The cyclical variations of the water level coincide with the cyclicality of the atmospheric precipitation. The integral difference curve reveals the phases of low (precipitation below normal) and high (precipitation above normal) moisture content of the territory (Obyazov, 2011). Long-term changes in Lake Arakhley's water levels are shown in Figure 2.

The water level was highest in 1962 and decreased over the following year. The decline in the water level slowed between 1967-1968 then increased until 1972. The next low-water phase continued until 1980, at which point the water level increased over the next 4-6 years. Water level fluctuations continued until 1990-1991. In 2008 the water level was close to the absolute minimum (Obyazov, 2011, 2014). We observed the minimum water level in 2017-2018, when the level decreased by approximately $2 \mathrm{~m}$. This decrease caused a $50 \mathrm{~m}$ displacement of the water's edge, causing the littoral zone, composed of sand and gravel deposits, to disappear.

\subsection{Physical and chemical data}


98

99

100

101

102

103

104

105

106

107

108

109

110

111

112

113

114

115

116

117

118

119

120

121

122

123

124

125

126

127

128

We used data from 2011, 2013, 2014, and 2016-2018 to analyze the long-term dynamics of hydrochemical parameters (Tsybekmitova \& Subbotina, 2013; Tsybekmitova et al., 2020). Hydrochemical data taken during the low-water period in Lake Arakhley show the state of its ecosystem (Fig. 2). Samples were collected from the surface and bottom layers using a Schindler-Patalas trap (PB-6, Borok, Russia). Surface horizon samples were taken $0.10 \mathrm{~m}$ below the water surface level, and bottom water samples were taken $0.10 \mathrm{~m}$ above the bottom. We conducted a chemical analysis of the water to identify nitrites using Griss reagent, nitrates (reduction to nitrites with the Griss reagent), ammonium ions (using the Nessler reagent), phosphates (with a reagent mixed with ascorbic acid), and total phosphorus (by combustion with potassium persulfate). The organic carbon concentration was determined by adding wet potassium dichromate oxidation (COD) and permanganate oxidation (PO) to lake water samples. These methods are described in detail by Adamovich et al. (2019). Concentrations were determined using a Spekol-1300 spectrophotometer. We used the ion chromatography system ICS-1600 and a Profile Plus inductively coupled plasma atomic emission spectrometer to determine the macro- and micro-components of water with $2 \%$ accuracy. The physical and chemical parameters of water $(\mathrm{pH}$, total dissolved solids, water temperature, electrical conductivity, oxidation-reduction potential, salinity, dissolved oxygen content, and turbidity) during sampling were measured using AQWA-READER (Germany). These methods have been used since 2000 to monitor Lake Arakhley long term.

\subsection{Phytoplankton data}

Phytoplankton samples were taken in May-June, July-August, October, and December of 2017-2018. We used data from the following periods to analyze the long-term dynamics of phytoplankton: 1966-1969 (Morozova, 1975, 1981), 1970-1971 (Morozova \& Shishkin, 1973; Morozova, 1981), 1988 and 1994-1995 (Ogly, 1993, 1995), and 2008-2009 (Tashlykova \& Koryakina, 2013).

Phytoplankton was collected from $0.5-1.0 \mathrm{~L}$ water samples taken from two or three horizons (surface, transparency, bottom) using the Schindler-Patalas sampler (PB-6, Borok, Russia) in the deep-water sites of the lake. Quantitative samples were fixed with a $4 \%$ formalin solution and quality samples were fixed with Lugol's solution. The samples were prepared using the sedimentary method and each sample was processed separately. Algae were counted according to the Hansen method (Sadchikov, 2003) on a counting plate. The biomass was 
129 determined based on the volume of individual algae cells or colonies and their geometric figures.

130 The specific weight was taken equal to one unit. Abundance and biomass were calculated as a 131 weighted arithmetic mean (Sadchikov, 2003). Taxon classification and algae group synonymy 132 were taken from the algological site AlgaeBase (Guiry and Guiry (C) 1996-2020). Species 133 diversity was calculated using Shannon's index (Shanon \& Weaver, 1963). The evenness or 134 equitability index was calculated using Pielou's formula (Pielou, 1967).

\section{2.4. Macrophytes data}

136 Water plants were studied using their ecological profiles (Yunnatov, 1964; Katanskaya, 137 1981), which reflected the distribution of aquatic phytocenoses at specific depths. Ten meter138 wide profiles were observed from the water edge to the maximum depth at which the plant grew. 139 Our observations included registering the species diversity, selecting the phytomass of plants, 140 and recording the depth of the water and the nature of the soil. Plants were collected from the 141 reservoir using a cat anchor with a metal mesh, which could also collect small plants. The cat 142 anchor was cast along the depth change gradient five to 15 times, depending on the density of the 143 communities. We studied eight profiles around the lake, covering the entire coastal area. Plant 144 phytomass was selected using a device for the quantitative accounting of gammarids (KUG) with 145 a capture area of $0.25 \mathrm{~m}^{2}$ (Bazarova \& Itigilova, 2006). The phytomass data are given in their 146 absolute dry value. We listed the dominant species sequentially to create a graphical description 147 of the composition and structure of vegetation in the ecological series with increasing depths. In

148 the ecological row of macrophytes unidirectional changes in communities are indicated by 149 single-pointed arrows. Double-pointed arrows indicate moving species; plus signs indicate 150 species forming communities at the same depth.

\subsection{Data Analysis}

We used Microsoft Excel and XLSTAT (Addinsoft, USA) to conduct the statistical and mathematical analyses of the findings. Redundancy analysis was performed to illustrate the correlation between the composition of the plankton and abiotic factors (Table 2). The absolute value of the load above 0.90 was considered to be significant.

The data were normalized by dividing the initial data by the standard deviation of the corresponding variables (Shipunov et al., 2014).

\subsection{Physical and chemical parameters of the lake ecosystem}


The physical and chemical parameters of environmental waters depend on the dissolution

161

162

163

164

165

166

167

168

169

170

171

172

173

174

175

176

177

178

179

180

181

182

183

184

185

186

187

188

189

190

and chemical weathering of rocks and biogeochemical processes in the soils of the catchment area and bottom sediments of water bodies. We show the specific physical and chemical parameters of the lowest water level (Fig. 2) in Table 3.

The temperature exchange between the water, atmosphere, and bottom sediments resulted in stratified thermal conditions in 2017 and 2018 with a gradient slightly above $3{ }^{\circ} \mathrm{C}$ between the surface and bottom layers (Table 3). The lake water was slightly alkaline. The oxidationreduction potential (ORP) of the ecosystem in Lake Arakhley ranged from 200 to $218 \mathrm{mV}$, creating oxidative conditions and a number of elements in their highest valence. The ORP values of the surface and bottom horizons of the water column differed slightly due to more favorable oxygen conditions in the surface water layer. The oxygen concentration in the surface horizon was higher (11.4 $\left.\mathrm{mg} \mathrm{O}_{2} \mathrm{~L}^{-1}\right)$ compared to the bottom layers $\left(8.8 \mathrm{mg} \mathrm{O}_{2} \mathrm{~L}^{-1}\right)$. There was a slight difference between the parameters of the surface and bottom water layers in terms of TDS and EC. Lake Arakhley is a low-mineralized freshwater lake with regard to total dissolved solids. We determined the main chemical composition and concentration values of specific elements (Table 3) and found that the water was of the hydrocarbonate class with a calcium-sodium group. The contrast analysis of macro- and microelement compositions indicated that the values did not exceed MPC. However, manganese concentration was 86 times higher than the MPC in the bottom water layers (Table 3).

Biogenic elements in the lake during the most productive summer period are shown in Table 4.

The nitrate form of nitrogen was dominant during the summer period. The nitrites and ammonium ions were minimal. The concentration of phosphorus was greater in the bottom layers compared to the surface layers. The organic matter was of autochthonous origin in the PO/COD ratio.

The analysis of year-to-year variations of biogenic elements showed that the ammonium and nitrite-nitrogen concentrations declined from 2011 to the present day, while the concentration of nitrates increased (Figure 3).

According to the results from 2011-2018, the PO/COD ratio was below 50\%, which indicates the autochthonous origin of the organic matter. The concentration of organic matter resistant to oxidation (COD) increased since 2013, but has not reached the level of 2011. The 
191 content of easily-oxidized organic substances (PO) is consistent according to the data of 20111922018 (Figure 4).

193 The analysis of year-to-year variations of the concentration of phosphates and total 194 phosphorus showed that their concentrations decreased in 2013-2018 compared to 2011 (Figure $1954)$.

3.2. Phytoplankton composition

A total of 39 taxa ranking below the genus level were detected in the lake's phytoplankton sampled from the central zone between 2017-2018 (Table 5).

There were 97 algae taxa recorded from the lake's center and coastal areas during the spring-to-summer period of 2017 (Tashlykova, 2019). The most diverse groups were the diatoms (Bacillariophyta), green algae (Chlorophyta), and golden algae (Chrysophyta) comprising 79.9 \% of the total identified taxa. Among the most frequently identified species were the following: Lindavia comta (Kützing) Nakov, Gullory, Julius, Theriot \& Alverson, Fragilaria crotonensis Kitton, F. radians (Kützing) D.M.Williams \& Round, Ulnaria ulna (Nitzsch) Compère in Jahn et al., Nitzschia graciliformis Lange-Bertalot \& Simonsen, Chrysococcus rufescens Klebs, Dinobryon cylindricum O.E. Imhof, D. divergens O.E. Imhof, D. sertularia O.E.Imhof, Kephyrion spirale (Lackey) Conrad, and Oocystis marssonii Lemmermann.

The value of the weighted average abundance and biomass is shown in Figure 5.

Algae's quantitative development in the spring was insignificant when compared with the predominance of small-sized Chrysophyta. Algocenoses composition was comprised of Chrysophyta (10-75 \% of total taxa and 30-92 \% of the overall biomass) and Bacillariophyta (20$85 \%$ of total taxa and $10-60 \%$ of the overall biomass). The total number of algae and overall

212 biomass increased in the summer by an order of magnitude due to a measurable growth of large 213 diatoms. Bacillariophyta prevailed in the phytoplankton with 60-80\% of total taxa and 50-95\% 214 of the overall biomass. The winter season was similarly marked by the predominance of Bacillariophyta in the algocenosis. We assessed the biodiversity in phytoplanktonocenoses using 216 the Shannon and Pielu indices. The phytoplankton of the lake was characterized by high values 217 of these indices, which demonstrates the complexity and high diversity of the community. The 218 Shannon index varied from 2.97 to 3.11 in the spring and the Pielou index ranged from 0.52219 0.76. In the summer, the value of the Shannon index was 1.27-1.38 and the Pielou index varied 220 from 0.15 to 0.28 . These values correspond to algae's seasonal distribution. The maximum 
221 values of the Shannon index are recorded in the spring and autumn, and the minimum values are

222 recorded in the winter and summer.

223 From 1966 to 1969, the lake's algocenosis featured abundant Cyclotella comta Kützing, 224 (currently Lindavia comta) (Guiry \& Guiry, 2020) (Yunnatov, 1964; Morozova \& Shishkin, 225 1973). The lake was dominated by Asterionella formosa Hassall from 1970 to 1971 (Morozova, 226 1981; Morozova \& Shishkin, 1973), A. formosa (Ogly, 1993, 1995) from 1990 to 1995, 227 Puncticulata comta (Kützing) H. Hakansson (currently L. comta) from 2008 to 2009 (Tashlykova, 228 2018), and L. comta from 2017 to 2018 (Table 6). The aforementioned distribution of the dominant species 229 corresponds to the alternate phases of the hydrological cycle. L. comta was dominant during the 230 dry years, while $A$. formosa was prevalent in high-water years.

231 There is inconsistent data on the quantitative development of algae in different periods of 232 the hydrological cycle. The average annual biomass is shown in Table 6. According to these 233 data, the highest biomass values were recorded for 1966, 1994-1995, 2008-2009, and 2017-2018.

\subsection{Macrophyte communities}

There are two species of charovaceae, one species of bryophytes, and 58 species of vascular plants recorded in Lake Arakhley. The maximum growth depth of lacustrine vegetation decreased from $11.0 \mathrm{~m}$ to $4.5 \mathrm{~m}$ from 1967 to 2018 and the wide strip of Nitella opaca (Bruz.) Ag and Fontinalis hypnoides Hartm disappeared. From 1967 to 1974, these species occupied isobaths $7.0-11.0 \mathrm{~m}$. The communities of $N$. opaca were still observable at four to six-meter depths along the western and eastern shores of the lake from 1998 to 2000. Moss F. hypnoides was found at a depth of $4 \mathrm{~m}$ on the lake's northern coast (Bazarova \& Itigilova, 2006). N. opaca and $F$. hypnoides populations have not been registered since 2006.

The analysis of the long-term macrophyte vegetation dynamics showed that communities of nine species were dominant in 1967 (Figure 6) and occupied approximately 44\% of the littoral area. These communities were characterized by low-density thickets. In terms of the overgrowth area and phytomass value, the dominant species were Charophyta, including the deep-water species of Nitella opaca, and the shallow-water species of Chara arcuatofolia (Figure 6). Decreased Ch. Arcuatofolia in 1974 led to an increase in N. opaca thickets density, and the start of the active development of vascular plants. In 1998, a sharp reduction in $N$. opaca thickets was recorded and an increase in the phytomass of L. trisulca and Ceratophyllum demersum was 
252 was preserved from 2017-2018 with $C$. demersum as the dominant vegetation. Plant 253 communities grew from the water's edge and were represented by Potamogeton perfoliatus L., 254 Potamogeton pectinatus (L.), and Myriophyllum sibiricum Kom. Chara arcuatofolia Vilh 255 populations were found at depths of of 1.5-2.0 $\mathrm{m}$ and $C$. demersum L. grew at greater depths. 256 Lemna trisulca L. populations were found in depressions on the lake bottom at depths of $3.0 \mathrm{~m}$, 257 whereas Potamogeton praelongus Wulf was observed at the maximum depths of plant growth 258 (4.5 m). The abundance of M. sibiricum communities indicated an increased eutrophicity of the 259 littoral zone. During this period, splash water bodies were formed on the coastal areas of the lake 260 with Ch. arcuatofolia (Kuklin \& Bazarova, 2019). A slight rise in the water level in 2018 did not 261 cause significant changes in the vegetation. However, the flooding of the coastal strip initiated 262 the development of helophyte communities represented by the thinned strip of Scrispus sp. Maximum plant germination occurred at a depth of approximately $4.5 \mathrm{~m}$, which 264 sequence: $P$. amphybia $($ depths $\approx 0.2-0.8 \mathrm{~m}) \rightarrow$ P. perfoliatuis $(\approx 1.0-1.5 \mathrm{~m}) \rightarrow$ Ch. arcuatofolia $(\approx 2.0 \mathrm{~m}) \rightarrow$ L. trisulca $\leftrightarrow$ C. demersum $\leftrightarrow$. praelongus $(\approx 3.0-7.0) \rightarrow N$. opaca $\leftrightarrow F$. hypnoides. $(\approx 7.0-11.0)$. In the period of 1998-2000, this row decreased but maintained its general structure: P. amphybia $(\approx 0.5 \mathrm{~m}) \rightarrow P$. perfoliatuis $(\approx 1.0 \mathrm{~m}) \rightarrow$ Chara arcuatofolia $(\approx$ $2.0 \mathrm{~m}) \rightarrow$ L. trisulca $(\approx 3.0 \mathrm{~m}) \leftrightarrow$ C. demersum $(\approx 4.0 \mathrm{~m}) \leftrightarrow P$. praelongus $(\approx 5.0 \mathrm{~m}) \rightarrow N$. opaca $(\approx 6.0 \mathrm{~m})$. Observations made in 2017-2018 revealed a decrease in the depth of plant growth and a violation of the clearly-expressed belt structure of vegetation. The row was featured the following species: $P$. perfoliatuis $+P$. pectinatus + M. sibiricum $(\approx 0.1-0.8 \mathrm{~m}) \rightarrow$ Ch. arcuatofolia $(\approx 1.8 \mathrm{~m}) \rightarrow$ C. demersum + P. praelongus $(\approx 2.5-4.5 \mathrm{~m})$. During the low-water period of 2017-2018, there was no clear correlation to the depths and the ecological series was as follows: P. perfoliatuis $+P$. pectinatus + M. sibiricum $(0.1-0.8 \mathrm{~m})$, Ch. arcuatofolia $(1,8 \mathrm{~m}) \rightarrow$ C. demersum $+P$. praelongus $(2.5-4.5 \mathrm{~m})$. Consequently, the lake featured a complex mosaic vegetation structure that varied along a depth gradient. Helophytes communities only grow along the southwestern coast, whereas neystophytes are represented by a narrow strip of Persicaria amphibia (L) Gray along the southern and western coast with a well-developed hydatophyte community. 
We sought to identify the key factors that determined the change in the structural

284

285

286

287

288

289

290

291

292

293

294

295

296

297

298

299

300

301

302

303

304

305

306

307

308

309

310

311

312

parameters of phytoplankton in the central zone of Lake Arakhley from 2018-2019 (Tsybekmitova et al., 2020). We performed redundancy analysis and the first two components were selected, explaining $94.92 \%$ of the total variance (Figure 7).

The number of Chlorophyta and the biomass of Dinophyta showed a clear negative correlation. The number and biomass of Euglenophyta, the number of Dinophyta, the biomass of Cyanobacteria and Bacillariophyta, and the number of taxa of Cyanobacteria, Bacillariophyta, Chrysophyta, and Chlorophyta were positively correlated with the first major factor (RDA axis 1). These results explained a $74.12 \%$ variability of the community. The second major factor (RDA axis 2) explained a $20.80 \%$ variability of the pelagial communities. The number of microalgae and groups of Chlorophyta, Charophyta, Cyanobacteria, and Bacillariophyta demonstrated positive correlation with RDA axis 2. Abiotic factors had the most meaningful effect on biocenosis and the physical and chemical parameters of water (TDS, pH, EC, ORP, Turb and Sal) positively correlated with RDA axis 1. The biogenic elements (nitrites, ammonium, phosphates) negatively correlated with RDA axis 1. Depth and transparency were positively correlated with RDA axis 2 .

\section{Discussion}

Significant global climate shifts in recent decades are reflected in the amount of atmospheric precipitation. The long-term global warming trends have been demonstrated by a number of studies (Ji et al., 2014; Huang et al., 2016). Rising global temperatures have resulted in climatologically wet regions becoming wetter and dry regions becoming drier. However, these changes differ from the global perspective at the regional level. Our study area in the eastern sector of Central Asia is a monsoon type with annual atmospheric precipitation. Small climate cycles appear at 24-25 years and six-to-seven years within a 60-year cycle (Obyazov, 2011, 2014).

atmospheric precipitation. Research on the impact of climate change on the state of aquatic ecosystems is being conducted worldwide (Nöges et al., 2003; Adrian et al., 2006; Lewandowska \& Sommer, 2010; Zohary et al., 2020). However, few studies have been conducted on changes in aquatic ecosystems in the natural conditions of North Asia due to fluctuations in the water levels 
313 of lakes. The research is mainly focused on anthropogenic impacts or some species of aquatic 314 organisms (Leira \& Cantonati, 2008).

315 The lake's mountainous conditions and its fluctuating continental subarctic climate affect 316 the physical and chemical characteristics of its ecosystem. The nutrient supply for phytocenoses 317 largely depends on the ecological systems and on the interaction of the catchment-lake system 318 (Carpenter et al., 1998; Bornette \& Puijalon, 2011; Nöges et al., 2011; Paerl et al., 2011). 319 Nutrient runoff is affected by changes in the amount and dynamics of precipitation (Freeman et 320 al., 2001; Tranvik \& Jansson, 2002).

321 The concentration of nutrients, including ammonium forms of nitrogen, is one of the 322 indicators of anthropogenic pressure on the catchment, especially when considering its 323 agricultural applications (Bornette \& Puijalon, 2011; Wang et al., 2014). Research has shown 324 that in 2011-2018, the concentration of ammonium nitrogen decreased, indicating a decrease in 325 the flow of water from the catchment area. In dry years, the PO/COD ratio is below 50\%, which 326 indicates the autochthonous origin of organic matter. Many studies have shown the link between 327 inorganic phosphorus and iron, which binds inorganic P in the humic acid complex (Paludan \& 328 Jensen, 1995; Paerl et al., 2011; Chen et al., 2018). The oxidation-reduction potential (ORP) of 329 Lake Arakhley's ecosystem ranges from 200 to $218 \mathrm{mV}$, which creates oxidative conditions and 330 the presence of a number of elements in the highest form of valence (including $\mathrm{Fe}^{3+}$ ). In high331 water years, the iron content ranged from 0.10 to $0.35 \mathrm{mg} / \mathrm{L}$ (Usmanov \& Zhilin, 2002). In dry 332 years, its concentration decreased by almost as twice compared to high-water years (Table 3). A 333 decrease in the iron content led to a decrease in the content of inorganic phosphorus (Fig. 4). The 334 decrease in the level of nitrogen and phosphorus concentrations in dry years was studied by Coppens et al. (2016). Alterations in the lake's nutrient concentrations were related to precipitation and inflow volumes.

The findings from 2017-2018 indicate the complexity of the structure and high diversity of the phytoplankton community in the dry period. Phytoplankton biodiversity indices were not calculated during the following periods: 1966-1969, 1970-1971, 1988 and 1994-1995, 20082009. In 1966-1976, there were 144 forms of algae identified in the species composition (Morozova, 1981; Morozova \& Shishkin, 1973); in 1988 and 1994-1995 there were 103 taxa 342 identified (Ogly, 1993, 1995), in 2008-2009 there were 110 taxa identified (Tashlykova \& 343 Koryakina, 2013). There were 97 taxa recorded at the rank below genus in the spring and 
344 summer of 2017 (Tashlykova, 2019). Taxonomic diversity was determined by diatoms, green, 345 golden, and cyanobacteria as reported in previous studies (Morozova, 1981; Morozova \& 346 Shishkin, 1973; Tashlykova \& Koryakina, 2013). The taxonomic structure and abundance of

347 phytoplankton species remained at the levels of the 1960s, 1970s, and 2000s in agreement with 348 the ecological modulation.

Phytoplankton's seasonal dynamics are determined by the dynamics of 350 hydrometeorological conditions. In 2017-2018, two abundance and biomass peaks were 351 distinguished in phytoplankton development, with the first being in the summer. This was the 352 most pronounced due to the development of three groups of algae: green, diatoms, and 353 cyanobacteria. The excessive development of cyanobacteria in the central zone and the lake was 354 not observed despite its low level. The second period in autumn was poorly-expressed due to the 355 development of diatoms, which was also noted in previous studies. However, in the summer of 1970-1989 (Morozova, 1981; Ogly, 1993, 1995) cyanobacteria increased in number and biomass.

Notably, research on Lake Arakhley beginning at 1966 has shown that a high phytoplankton biomass corresponds with periods of low-water levels and may be due to the size of the dominant algae species.

The data collected on the phytoplankton structure of the lake is comparable to that of other lakes (Grabowska et al., 2014; Liu et al., 2015 etc.). Similar findings on the significance of abiotic factors were obtained through laboratory analyses and stationary research in other water bodies (Bierman \& Dolan, 1981; Watson et al., 1997; Nalewajko \& Murphy, 2001; Tian et al., 2013; Chang et al., 2013; Wang et al., 2015; Yang et al., 2016; Yang et al., 2017 etc.). The condition of phytoplankton communities reflects the reaction of the species to such environmental changes as mixing, water heating, catchment, and physical and chemical properties causing changes in algo- and zoocenoses. These changes have been confirmed by the RDA analysis of the phytoplankton composition and abiotic factors.

Fluctuations in the water-level are one of the core factors affecting the biomass, diversity, composition, and structure of vegetation. Variations in environmental factors including light,

372 oxygen, temperature, and nutrients impact plant growth and germination (Nöges \& Nöges, 1999;

373 Geest et al., 2005; Yang et al., 2014). Fluctuations in the water-level impact aquatic vegetation 
374 by altering their amplitude and dynamic regime. Various macrophytes react differently to 375 fluctuations in the water level.

376 Macrophyte community struction in 2017-2018 and its long-term variations are largely

377 due to a decrease in the water-level of the lake. Different macrophyte species of identical life 378 forms may react differently to fluctuations in the water level (Tan et al., 2020). Ceratophyllum 379 demersum became more abundant when the water level fluctuated (Wang et al., 2016). The 380 lake's vegetable populations are typically formed under abiotic factors (Hill et al., 1998). A 381 review of the literature on the impact of climate change on aquatic vegetation shows that an 382 increase in temperature affects the growth and development of some plant species (Hossain et al., 383 2017). However, the increase in temperature had little effect on macrophytes compared to the 384 effect of nutrients (Feuchtmayr et al., 2007; Bornette \& Puijalon, 2011). According to Forsberg 385 (1964, 1965), when the $\mathrm{P}_{\text {total }}$ content is higher than $0.02 \mathrm{mg} \mathrm{L}^{-1}$, the growth of Charophyta is 386 inhibited. Analyzing the phosphorus concentration in Lake Arakhley reveals that there was an 387 increase in the phosphorus content up to $0.15 \mathrm{mg} \mathrm{L}^{-1}$ in 2011 , which led to the disappearance of 388 the deep-sea species of the Charophyta algae and mosses.

\section{5. Conclusion}

Cyclic fluctuations in water levels transform the composition of biogenic substances.

391

392

393

394

395

396

397

398

399

400

401

402

403

404

This, in turn, affects the composition of the dominant complex of the phytocenoses. In dry years, L. comta was dominant in the phytoplankton community, while A. formosa prevailed during high-water years. The hydrophyte community was monodominant and represented by $C$. demersum populations in dry years. During these periods, macrophyte growth was observed in shallower areas, which were overgrown and lacked complexity. Thicket density and the community diversity in the shallow zone also increased. The lake's vegetation cover tended to be more diverse during high-water years.

RDA analysis of the correlation between abiotic factors and biocenosis was conducted to determine the parameters of the dry season. Our results indicated that the physical and chemical parameters of water (TDS, $\mathrm{pH}, \mathrm{EC}, \mathrm{ORP}, \mathrm{Turb}$, and Sal), biogenic elements (nitrites, ammonium, and phosphates), depth, and transparency were the most influential abiotic factors leading to the change biodiversity of Lake Arakhley. 
405

406

407

408

409

410

411

412

413

414

415

416

417

418

419

420

421

422

423

424

425

426

427

428

429

430

431

432

433

434

435

436

437

438

439

440

441

442

443

444

445

446

447

448

\section{REFERENCES}

Adamovich B.V., Nikitina L.V., Mikheeva T.M.,Kovalevskaya R.Z., Veres Y.K., Zhukova T.V., Medvinsky A.B., Rusakov A.V., Nurieva N.I., Radchikova N.P.,

Chakraborty A. 2019. Relations between variations in the lake bacterioplankton abundance and the lake trophic state: evidence from the 20-year monitoring. Ecological Indicators 97: 120-129. https://doi.org/10.1016/j.ecolind.2018.09.049.

Adrian R, Wilhelm S, Gerten D. 2006. Life-history traits of lake plankton species may govern their phenological response to climate warming. Global change biology 12(4):652-661 DOI 10.1111/j.1365-2486.2006.01125.x.

Bazarova BB, Itigilova VTs. 2006. Long-term production dynamics of aquatic vegetation in the Arakhlei Lake (Eastern Transbaikalia). Biology Bulletin 33(1):68-72 DOI 10.1134/S1062359006010109.

Bierman VJr, Dolan DM. 1981. Modeling of phytoplankton-nutrient dynamics in Saginaw Bay, Lake Huron. Journal of Great Lakes Research 7:409-439.

Bornette G, Puijalon S. 2011. Response of aquatic plants to abiotic factors: a review. Aquatic Sciences 73:1-14 DOI 10.1007/s00027-010-0162-7.

Carpenter SR, Caraco NF, Correll DL, Howarth RW, Sharpley AN, Smith VH, 1998. Nonpoint pollution of surface waters with phosphorus and nitrogen. Ecological applications 8(3):558-568 DOI 10.1890/1051-0761(1998)008[0559:NPOSWW]2.0.CO;2.

Chang T, Xue TL, Hai YP, Wen RH, Jun X. 2013. Seasonal dynamics of phytoplankton and its relationship with the environmental factors in Dongping Lake, China. Environmental Monitoring and Assessment 185:2627-2645 DOI 10.1007/s10661-012-2736-4.

Chen M, Ding S, Chen X, Sun Q, Fan X, Lin J, Ren M, Yang L, Zhang Ch. 2018. Mechanisms driving phosphorus release during algal blooms based on hourly changes in iron and phosphorus concentrations in sediments. Water Research 133(15):153-164.

Coppens J., Özen A., Tavşanoğlu Ü.N., Erdoğan S., Levi E.E., Yozgatlıgil C., Jeppesen E., Beklioğlu M. 2016. Impact of alternating wet and dry periods on long-term seasonal phosphorus and nitrogen budgets of two shallow Mediterranean lakes. Science of The Total Environment 563-564: 456-467. https://doi.org/10.1016/j.scitotenv.2016.04.028.

Donchyts G, Baart F, Winsemius H, Gorelick N, Kwadijk J, Giesen N. 2016. Earth's surface water change over the past 30 years. Nature climate change 6:810-813 DOI 10.1038/nclimate3111.

Feuchtmayr H, McKee D, Harvey IF, Atkinson D, Moss B. 2007. Response of macroinvertebrates to warming, nutrient addition and predation in large-scale mesocosm tanks. Hydrobiologia 584:425-432 DOI 10.1007/s10750-007-0588-7.

Forsberg C. 1964. Phosphorus, a maximum factor in the grow of Characeae. Nature, 201:517-518.

Forsberg C. 1965. Ecological and physiological studies of Charophytes. Abstract of Uppsala Dissertations in Science. 53:275-290.

Freeman C, Evans CD, Monteith DT, Reynolds B, Fenner N. 2001. Export of organic carbon from peat soils. Nature 412: 785. doi:https://doi.org/10.1038/35090632.

Geest GV, Wolters H, Roozen F, Coops H, Roijackers R, Buijse A, Scheffer M. 2005. Water-level fluctuations affect macrophyte richness in floodplain lakes. Hydrobiologia 539:239248 DOI 10.1007/s10750-004-4879-y. 
Grabowska M, Glińska-Lewczuk K, Obolewski K, Burandt P, Kobus S, Dunalska, J, Skrzypczak A. 2014. Effects of hydrological and physicochemical factors on phytoplankton communities in floodplain lakes. Polish Journal of Environmental Studies 23(3): 713-725.

Guiry MD, Guiry GM. 2020. Algaebase. World-wide electronic publication (C 1996-2020. National University of Ireland, Galway. Available at http://www.algaebase.org/ (accessed 10 January 2020).

Hill NM, Keddy PA, Wisheu IC. 1998. A hydrological model for predicting the effects of dams on the shoreline vegetation of lakes and reservoirs. Environmental management 22:723736.

Hossain K, Yadav S, Quaik S, Pant G, Marathi AY, Ismail N. 2017. Vulnerabilities of macrophytes distribution due to climate change. Theor Appl Climatol 129:1123-1132 DOI 10.1007/s00704-016-1837-3.

Huang J., Ji M., Xie Y., Wang Sh., He Y., Ran J. 2016. Global semi-arid climate change over last 60 years. Clim Dyn. 46: 1131-1150. DOI 10.1007/s00382-015-2636-8.

Izaguirre I, Sánchez ML, Schiaffino MR, Farrell IO, Huber P, Ferrer N, Zunino J, Lagomarsino L, Mancini M. 2015. Which environmental factors trigger the dominance of phytoplankton species across a moisture gradient of shallow lakes? Hydrobiologia 752:47-64 DOI 10.1007/s10750-014-2007-1.

Ji F., Wu Z., Huang J., Eric P. 2014. Evolution of land surface air temperature trend. Nat Clim Change. doi:10.1038/nclimate2223/.

Katanskaya VM. 1981. Higher water vegetation of continental reservoirs of the USSR. Methods of study. Leningrad: Nauka.

Koch EW. 2001. Beyond light: physical, geological, and geochemical parameters as possible submersed aquatic vegetation habitat requirements. Estuaries 24:1-17 DOI $10.2307 / 1352808$.

Kuang X, Jiao JJ. 2016. Review on climate change on the Tibetan Plateau during the last half centure. Journal of Geophysical Research Atmospheres. 121:3979-4007 DOI 10/1002/2015JD024728.

Kuklin AP, Bazarova BB. 2019. Macrophytes in the littoral of lake Arakhley in different states of water regime. Ekológia (Bratislava) 38(3):225-239 DOI 10.2478/eko-2019-0018.

Leira M., Cantonati M. 2008. Effects of water-level fluctuations on lakes: an annotated bibliography. In: Wantzen K.M., Rothhaupt KO., Mörtl M., Cantonati M., Tóth L.G., Fischer P. (eds) Ecological Effects of Water-Level Fluctuations in Lakes. Developments in Hydrobiology 204. Springer, Dordrecht. https://doi.org/10.1007/978-1-4020-9192-6_16

Lewandowska A, Sommer U. 2010. Climate change and the spring bloom: a mesocosm study on the influence of light and temperature on phytoplankton and mesozooplankton. Marine Ecology Progress Series 405:101-111 DOI 10.3354/meps08520.

Liu L, Yang J, Lv H, Yu X, Wilkinson DM, Yang J. 2015. Phytoplankton communities exhibit a stronger response to environmental changes than bacterioplankton in three subtropical reservoirs. Environmental Science and Technology 49:10850-10858 DOI 10.1021/acs.est.5b02637.

Liu X, Qian K, Chen Y. 2015. Effects of water level fluctuations on phytoplankton in a Changjiang River floodplain lake (Poyang Lake): implications for dam operations. Journal of Great Lakes Research 41(3): 770-779.

Melzer A. 1999. Aquatic macrophytes as tools for lake management. Hydrobiologia 395/396:181-190 DOI 10.1007/978-94-017-3282-6_17. 
Morozova TN, Shishkin BA. 1973. Annual changes in phytoplankton of some IvanoArakhley Lakes. In: Sizikov AI, ed. Limnological studies in Transbaikalia. Chita: Publishing House of the Transbaikal Branch of the Russian Geographical Society.

Morozova TN. 1975. Seasonal and Annual Changes in Phytoplankton of Ivano-Arakhley Lakes: Author's Abstract. Dis. ... Cand. Biol. Sciences. Irkutsk: Irkutsk State University.

Morozova TN. 1981. Phytoplankton of Arakhley Lake. Novosibirsk: Science Press.

Nalewajko C, Murphy TP. 2001. Effects of temperature and availability of nitrogen and phosphorus on the abundance of Anabaena and Microcystis in Lake Biwa, Japan: an experimental approach. Limnology 2(1):45-48 DOI 10.1007/s102010170015.

Nõges T, Nõges P. 1999. The effect of extreme water level decrease on hydrochemistry and phytoplankton in a shallow eutrophic lake. Hydrobiologia 408:277-283 DOI 10.1007/978-94017-2986-4_30.

Nõges $\overline{\mathbf{T}}$, Nõges P, Laugaste R. 2003. Water level as the mediator between climate change and phytoplankton composition in a large shallow temperate lake. Hydrobiologia 506:257-263 DOI 10.1023/B:HYDR.0000008540.06592.48.

Nõges P, Nõges T, Ghiani M, Sena F, Fresner R, Friedl M \& Mildner J. 2011. Increased nutrient loading and rapid changes in phytoplankton expected with climate change in stratified South European lakes: sensitivity of lakes with different trophic state and catchment properties. Hydrobiologia 667:255-270 DOI 10.1007/s10750-011-0649-9.

Obyazov VA, Usmanov MT, Zhilin VN. 2002. Hydrology. In: Pronin NM, ed. IvanoArakhley reserve: natural resource potential of the territory Chita: Publisher House "Poisk", 2127.

Obyazov VA. 2011. The hydrological regime of Transbaikalia lakes in a changing climate (using the example of Ivano-Arakhley Lakes). Water Management of Russia 3: 4-14.

Obyazov VA. 2014. Changes in the modern climate and assessment of their consequences for natural and natural-anthropogenic systems of Transbaikalia: Author's Abstract. Dis. ... Dr. Geogr. Sciences. Kazan Federal University, Kazan, Russia, 25 May 2014.

Ogly ZP. 1993. Phytoplankton of different types of lakes in Transbaikalia: Author's Abstract. Dis. ... Cand. Biol. Sciences. St. Petersburg: Publishing house of the State Research Institute of Lake and River Fishing.

Ogly, Z.P. 1995. Long-term observations of phytoplankton in the lakes of Central Transbaikalia. In: Strizova TA ed. Problems of ecology of the Baikal region, Novosibirsk: Nauka.

Paerl HW, Valdes LM, Pinckney JL, Piehler MF, Dyble J, Moisander PH. 2003. Phytoplankton photopigments as indicators of estuarine and coastal eutrophication. BioScience. 53(10):953-964 DOI 10.1641/0006-3568(2003)053[0953:PPAIOE]2.0.

Paerl HW, Hall NS, Calandrino ES. 2011. Controlling harmful cyanobacterial blooms in a world experiencing anthropogenic and climatic-induced change. Science of the Total Environment 409:1739-1745.

Palmer MA, Bel SL, Butterfield I. 1992. A botanical classification of standing waters in Britain: applications for conservation and monitoring. Aquatic Conservation: Marine and Freshwater Ecosystems 12:125-143 DOI 10.1002/aqc.3270020202.

Paludan C, Jensen HS. 1995. Sequential extraction of phosphorus in freshwater wetland and lake sediment: Significance of humic acids. Wetlands 15:365-373. DOI 10.1007/BF03160891. 
540

Pielou EC. 1967. The use of information theory in the study of the diversity of biological pollutions. Proc. 5th Berkeley symp., Math. Stat. Prob. 4:163-177.

Riis T, Hawes I. 2002. Relationships between water level fluctuations and vegetation diversity in shallow water of New Zealand lakes. Aquatic Botany 74:133-148 DOI 10.1016/S0304-3770(02)00074-8.

Sadchikov AP. 2003. The study methods of freshwater phytoplankton. Moscow: University and School Press.

Schindler DW. 1977. Evolution of phosphorus limitation in lakes. Science, NewSeries 195(4275): 260-262.

Shanon CE, Weaver W. 1963. The mathematical theory of communication. Urbana: University of Illinois Press.

Shipunov AB, Baldin EM, Volkova PA, Korobeynikov AI, Nazarova SA, Petrov SV, Sufianov VG. 2014. Visual statistics, we use R. Moscow: DMK Press.

Tan W, Xing J, Yang S, Yu G, Sun P, Jiang Y. 2020. Long term aquatic vegetation dynamics in Longgan Lake using landsat time series and their responses to water level fluctuation. Water 12(8):2178 DOI 10.3390/w12082178.

Tashlykova NA. 2018. Composition and structure of phytoplankton in the coastal and central parts of Arakhley Lake (Zabaikalsky territory) in spring and summer. Principy ekologii 7(3):31-47 DOI 10.15393/j1.art.2018.7403.

Tashlykova NA. 2019. The composition of algae in the Lake Arakhley during springsummer period (Transbaikal region). Acta Biologica Sibirica 5(1): 47-52. DOI: 10.14258/ABS.V5.I1.5190

Tashlykova NA, Koryakina EA. 2013. Phytoplankton. In: Pronin NM, ed. Ivano-Arakhley Lakes at the turn of the century: state and dynamics. Novosibirsk: Publishing House of the SB RAS, 115-119.

Tian C, Pei HY, Hu WR, Xie J. 2013. Phytoplankton variation and its relationship with the environmental factors in Nansi Lake, China. Environmental Monitoring and Assessment 185:295-310 DOI 10.1007/s10661-012-2554-8.

Tranvik LJ, Jansson M. 2002. Climate change (Communication arising): Terrestrial export of organic carbon. Nature 415: 861-862. doi:https://doi.org/10.1038/415861b.

Tsybekmitova GTs, Subbotina VN. 2013. Biogenic elements in the water of Lake Arakhley. In: Pronin NM, ed. Ivano-Arakhley Lakes at the turn of the century: state and dynamics. Novosibirsk: Publishing House of the SB RAS, 78-84.

Tsybekmitova GTs, Radnaeva LD, Tashlykova NA, Shiretorova VG, Tulochonov AK, Bazarova BB, Matveeva MI. 2020. The Effect of Climatic Shifts on Biodiversity of Phytocenosis: Lake Arakhley (Eastern Siberia, Russia). International Journal of Ecology \& Development 35 (3): 77-90. DOI 10.18411/0973-7308-2020-35-3-77-90.

Usmanov MT, Zhilin VN. 2002. Characterization of hydrochemical parameters. In: Gorlachev VP, ed. Ivano-Arakhley reserve: natural resource potential of the territory. Chita: Search Press, 66-70.

Wang M, Liu Z, Luo F, Lei G, Li H. 2016. Do amplitudes of water level fluctuations affect the growth and community structure of submerged macrophytes? PLOS ONE 11, e0146528 DOI 10.1371/journal.pone.0146528. 
583

584

585

586

587

588

589

590

591

592

593

594

595

596

597

598

599

600

601

602

603

604

605

606

607

608

609

610

611

612

613
Wang Y, Li Y, Feng L, Li Yu, Song L, Li H, Meng C, Wu J. 2014. Linking rice agriculture to nutrient chemical composition, concentration and mass flux in catchment streams in subtropical central China. Agriculture, Ecosystems and Environment 184:9-2 DOI 10.1016/j.agee.2013.11.007.

Wang YF, Zhao XL, He BH, Huang Q. 2015. Canonical correspondence analysis of summer phytoplankton community and its environmental factors in Hanfeng Lake. Huan Jing Ke Xue 36(3):922-927 DOI 10.1007/s10661-019-7847-8.

Watson SB, McCauley E, Downing JA. 1997. Patterns in phytoplankton taxonomic composition across temperate lakes of differing nutrient status. Limnology and Oceanography 42(3):487-495 DOI 10.4319/lo.1997.42.3.0487.

Winder M, Sommer U. 2012. Phytoplankton response to a changing climate. Hydrobiologia 698:5-16 DOI 10.1007/s10750-012-1149-2.

Yang J, Li E, Cai X, Wang Z, Wang X. 2014. Research progress in response of plants in wetlands to water level change. Water Science and Technology 12:807-813.

Yang J, Hong L, Yang J, Liu L, Yu X, Chen H. 2016. Decline in water level boosts cyanobacteria dominance in subtropical reservoirs. Science of the Total Environment 557558:445-452 DOI 10.1016/j.scitotenv.2016.03.094.

Yang JR, Lv H, Isabwe A, Liu L, Yu X, Chen H, Yang J. 2017. Disturbance-induced phytoplankton regime shifts and recovery of cyanobacteria dominance in two subtropical reservoirs. Water research 120:52-63 DOI 10.1016/j.watres.2017.04.062.

Yang K, Wu H, Qin J, Lin Ch, Tang W, Chen Y. 2016. Recent climate changes over the Tibetan Plateau and their impacts on energy and water cycle: a review. Global and Planetary Change. 112:79-91 DOI 10.1016/j.gloplacha.2013.12.001.

Yunnatov AA. 1964. Laying down environmental profiles and trial areas. Field geobotany. Moscow: Nauka.

Zhang Y, Jeppesen E, Liu X, Qin B, Shi K, Zhou Y, Thomaz SM, Deng J. 2017. Global loss of aquatic vegetation in lakes. Earth-Science Reviews 173:259-265 DOI 10.1016/j.earscirev.2017.08.013.

Zohary T, Flaim G, Sommer U. 2020. Temperature and the size of freshwater phytoplankton. Hydrobiologia 847(16) DOI 10.1007/s10750-020-04246-6. 
Figure 1

Figure 1. Schematic map of the Arakhley Lake

No

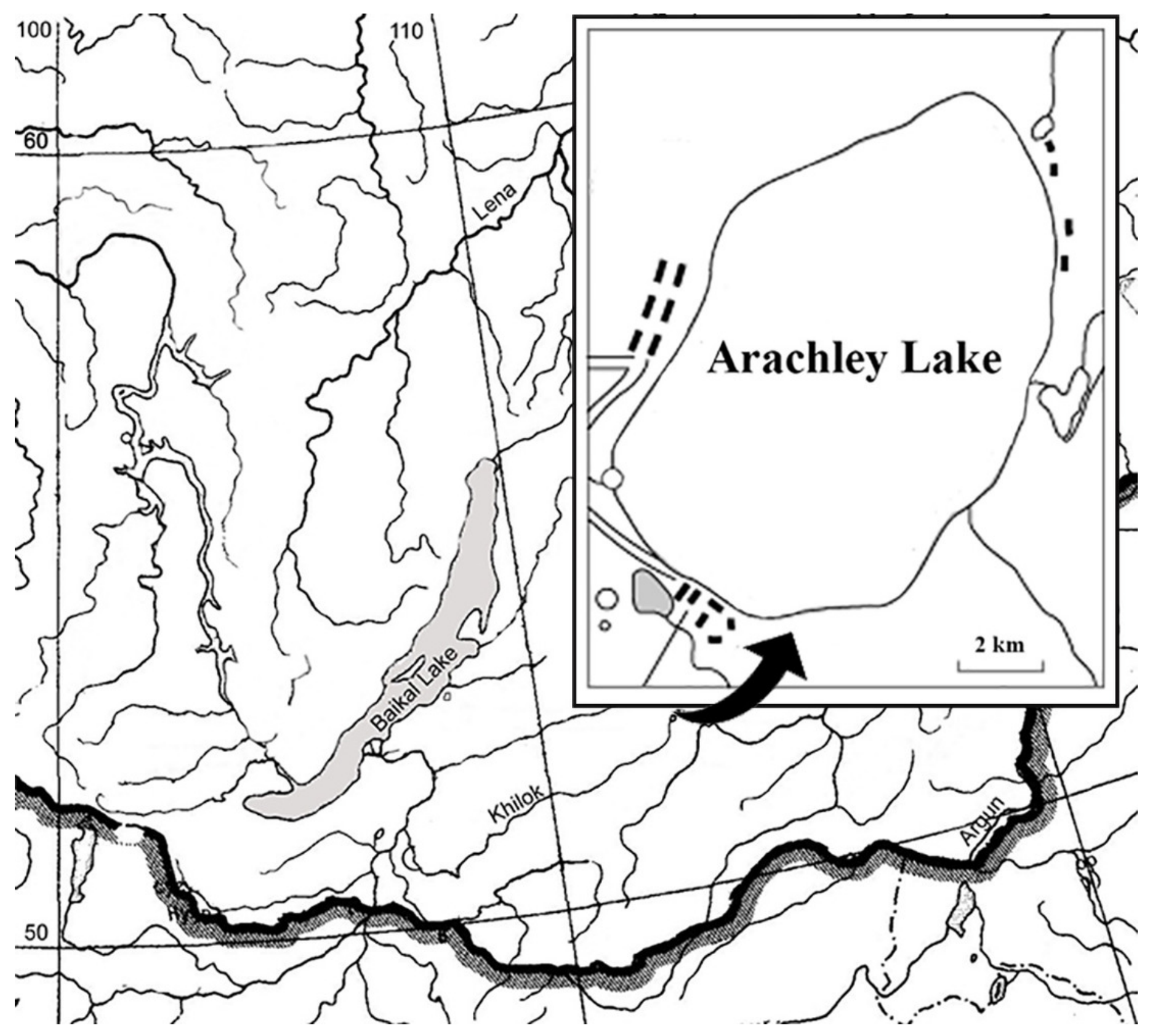


Figure 2

Figure 2. Integral difference curve of annual amounts of atmospheric precipitation (Obyazov, 2011) and changes in the water level of the Lake Arakhley. Hydrological post of Preobrazhenka village. Post zero mark - $963.1 \mathrm{~m}$ (Baltic height system - BS).

Нулевая отметка столба - 963,1 м (Baltic height system - BS).

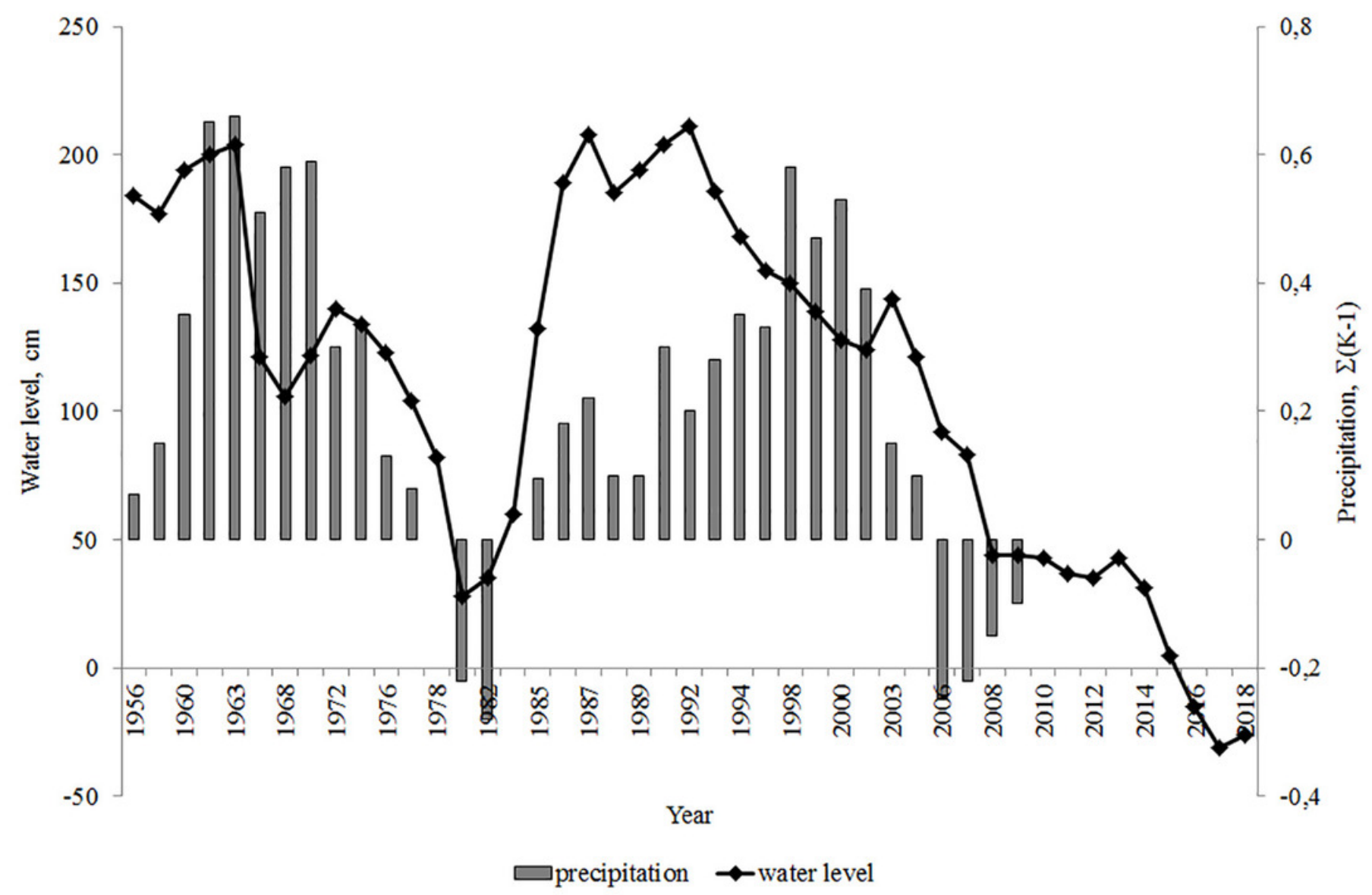


Figure 3

Figure 3. Average annual concentrations of nitrogen compounds in the Lake Arakhley

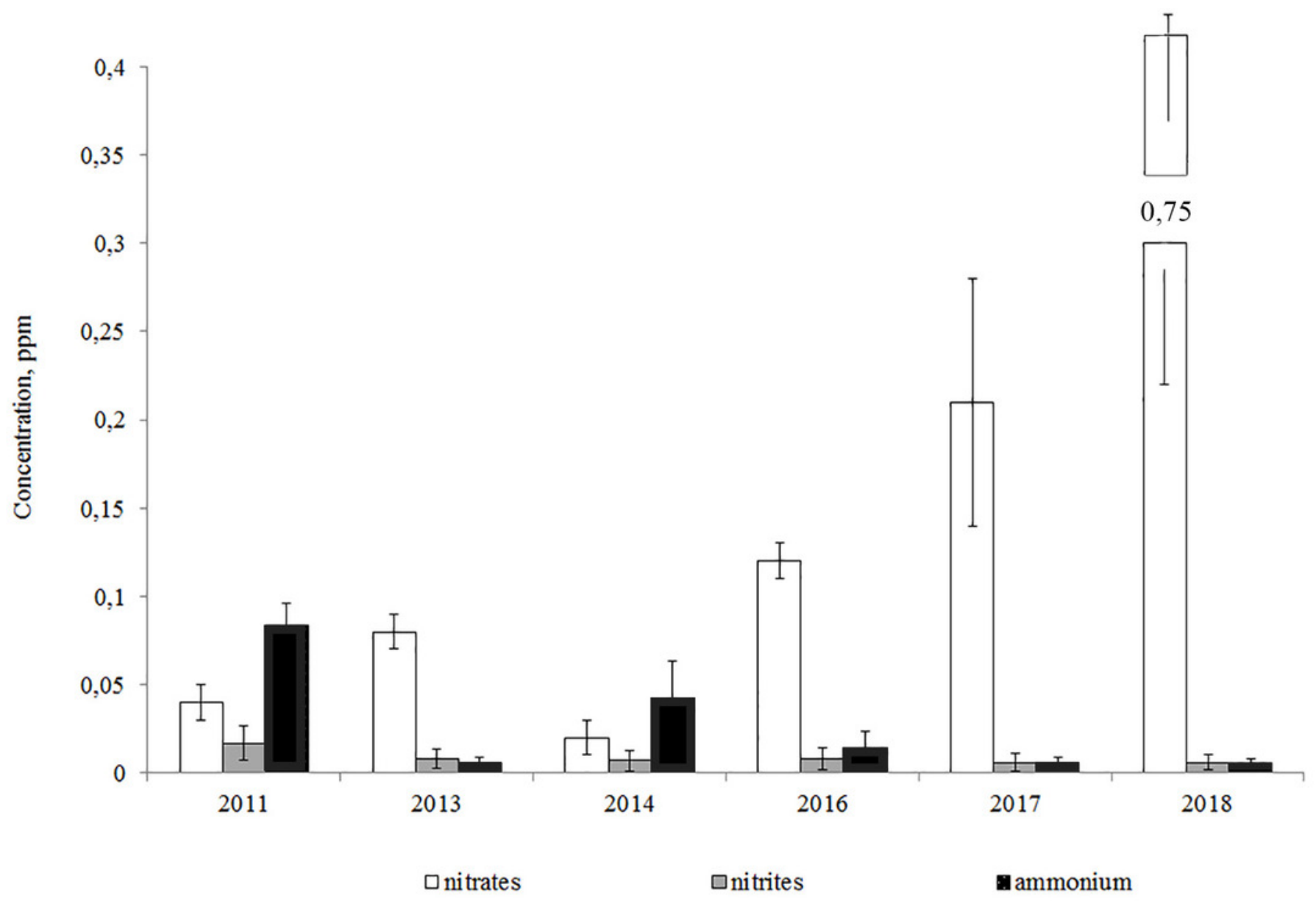


Figure 4

Figure 4. Average annual concentration of the easily oxidable organic matter and organic matter resistant to oxidation (A), phosphates and total phosphorus (B) in Lake Arakhley
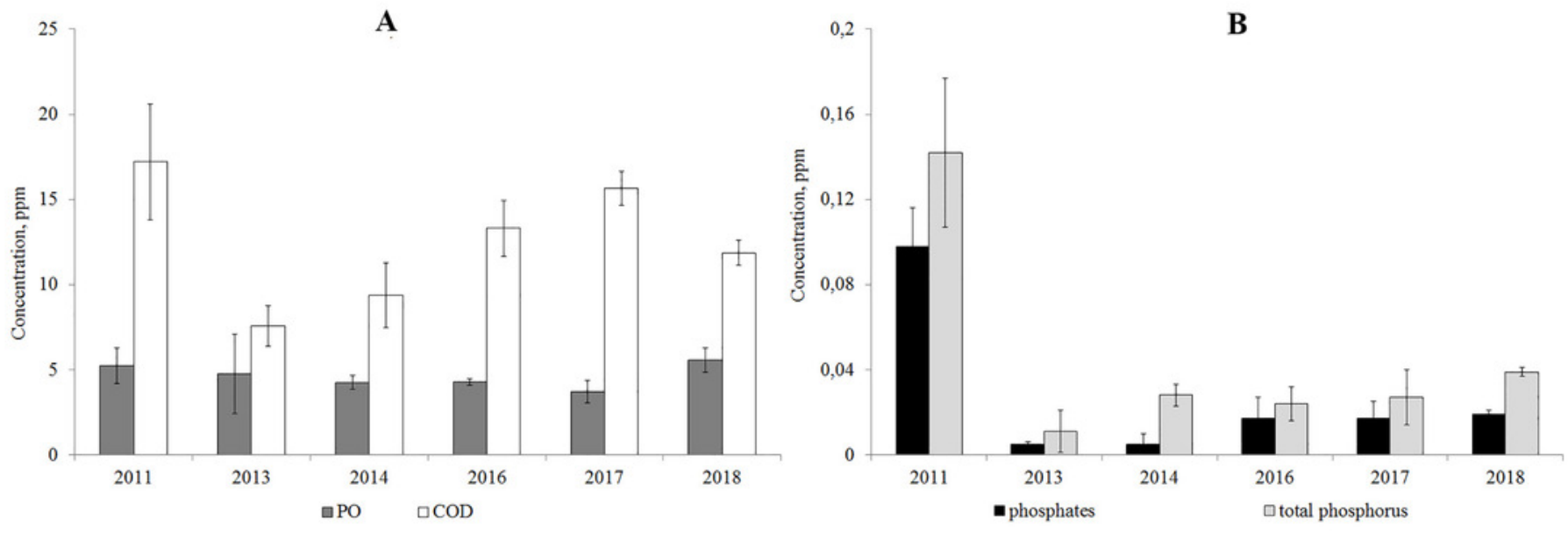
Figure 5

Figure 5. The weighted average abundance $\left(A, * 10^{3}\right.$ cell $\left.* \mathrm{~L}^{-1}\right)$ and biomass $\left(\mathrm{B}, \mathrm{mg} * \mathrm{~m}^{-3}\right)$ phytoplankton in the study period

No
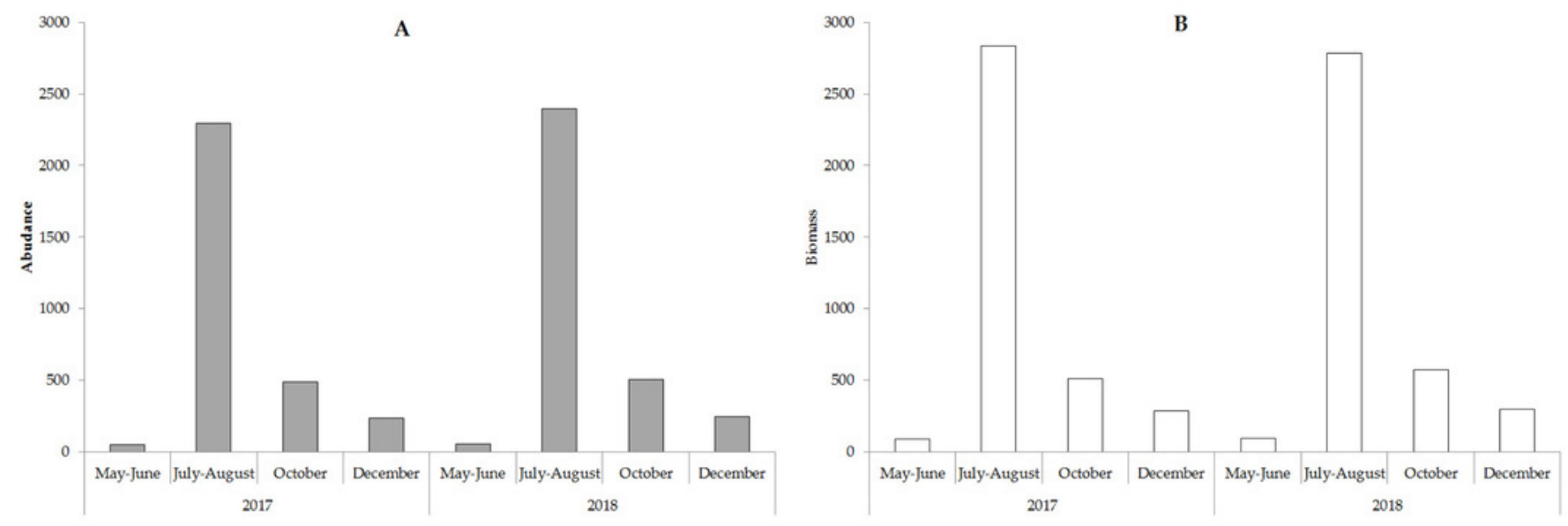


\section{Figure 6}

Figure 6. Long-term dynamics of macrophytes (by phytomass value) in Lake Arakhley

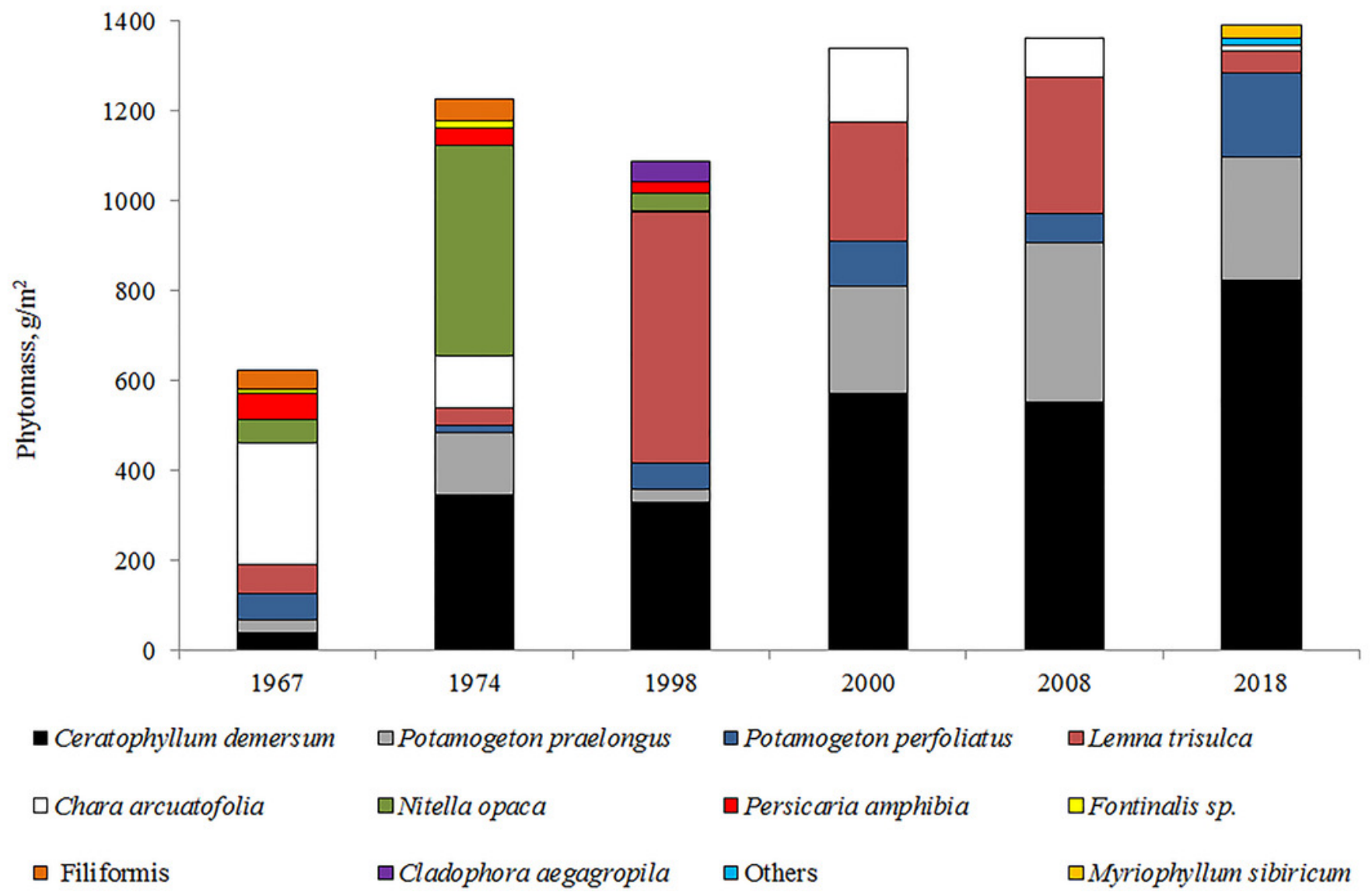


Figure 7

Figure 7. RDA analysis of phytoplankton composition and abiotic factors within the first two major factors in the central zone of the Arakhley Lake in 2017-2018 (Tsybekmitova et al., 2020)

No 


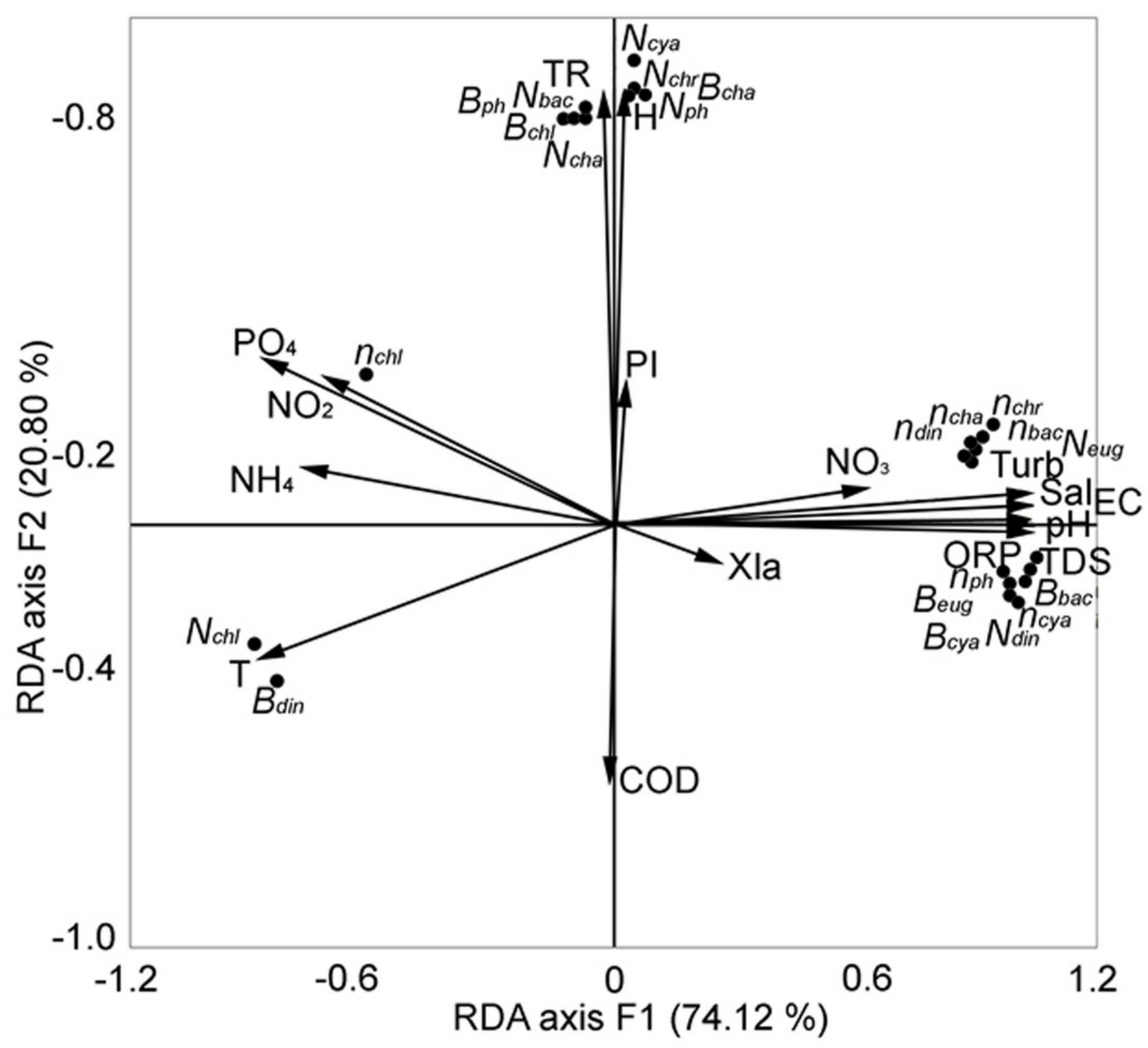




\section{Table 1 (on next page)}

Table 1. The main characteristics of the Arakhley Lake (Obyazov et al., 2002).

No 
Table 1. The main characteristics of the Arakhley Lake (Obyazov et al., 2002).

\begin{tabular}{ll}
\hline Characteristic, units & Arakhley \\
\hline & $52^{\circ} 48^{\prime}-52^{\circ} 10^{\prime} \mathrm{N}$, \\
geographical coordinates & $112^{\circ} 45^{\prime}-113^{\circ} 04^{\prime} \mathrm{E}$ \\
basin bottom elevation & $940-930 \mathrm{~m} \mathrm{BS}$ \\
surface area, $\mathrm{km}^{2}$ & 59.0 \\
water volume, km ${ }^{3}$ & 0.60 \\
length, km & 11.0 \\
max width, km & 6.7 \\
average width, km & 5.3 \\
max depth, m & 17.0 \\
average depth, m & 10.2 \\
shore length, m & 29.0 \\
catchment area, km & 256 \\
water exchange coefficient & 0.055 \\
trophic status & mesotrophic \\
\hline
\end{tabular}


Table 2 (on next page)

Table 2. Parameters and their abbreviations

No 
1 Table 2. Parameters and their abbreviations

\begin{tabular}{|c|c|c|c|}
\hline $\begin{array}{l}\text { Description of } \\
\text { a plankton }\end{array}$ & Abbreviation & $\begin{array}{l}\text { Description of } \\
\text { abiotic parameters }\end{array}$ & Abbreviation \\
\hline number & $\mathrm{n}$ & lake depth & $\mathrm{H}$ \\
\hline phytoplankton species & ph & water transparency & TR \\
\hline Cyanobacteria & cya & $\mathrm{pH}$ & $\mathrm{pH}$ \\
\hline Bacillariophyta & bac & total dissolved solids & TDS \\
\hline Chrysophyta & chr & water temperature & $\mathrm{T}$ \\
\hline Charophyta & cha & electrical conductivity & $\mathrm{EC}$ \\
\hline Chlorophyta & chl & $\begin{array}{l}\text { oxidation-reduction } \\
\text { potential }\end{array}$ & ORP \\
\hline Euglenophyta & eug & salinity & Sal \\
\hline Dinophyta & $\operatorname{din}$ & turbidity & Turb \\
\hline total number of & $\mathrm{N}$ & nitrites & $\mathrm{NO}_{2}$ \\
\hline \multirow[t]{6}{*}{ total biomass of } & $\mathrm{B}$ & nitrates & $\mathrm{NO}_{3}$ \\
\hline & & ammonium & $\mathrm{NH}_{4}$ \\
\hline & & phosphates & $\mathrm{PO}_{4}$ \\
\hline & & $\begin{array}{l}\text { permanganate } \\
\text { oxidability index }\end{array}$ & PI \\
\hline & & $\begin{array}{l}\text { chemical oxygen } \\
\text { demand }\end{array}$ & COD \\
\hline & & $\begin{array}{l}\text { chlorophyll a } \\
\text { concentration }\end{array}$ & Xla \\
\hline
\end{tabular}

2 


\section{Table 3 (on next page)}

Table 3. Average annual characteristics physical and chemical parameters in the central zone of the Lake Arakhley for the period open water between 2017 and 2018

Note: *MPC - the maximum permissible concentration for lakes fishery use in Russia (FAF, 2020). 
1 Table 3. Average annual characteristics physical and chemical parameters in the central

2 zone of the Lake Arakhley for the period open water between 2017 and 2018

\begin{tabular}{|c|c|c|c|}
\hline \multirow{2}{*}{$\begin{array}{c}\text { Physical and } \\
\text { chemical parameters }\end{array}$} & \multicolumn{2}{|c|}{ Water horizon } & \multirow[t]{2}{*}{ MPC* } \\
\hline & surface layer $(n=24)$ & bottom layer $(n=24)$ & \\
\hline $\mathrm{T},{ }^{\circ} \mathrm{C}$ & $12.2 \pm 2.3$ & $8.8 \pm 0.8$ & - \\
\hline $\mathrm{pH}$ & $7.8 \pm 0.2$ & $7.8 \pm 0.1$ & $6.5-8.5$ \\
\hline ORP, mV & $218 \pm 21.5$ & $200 \pm 23.3$ & - \\
\hline $\mathrm{EC}, \mu \mathrm{S} \mathrm{cm}-1$ & $230 \pm 6.7$ & $226 \pm 8.6$ & - \\
\hline TDS, mg L $\mathrm{L}^{-1}$ & $153 \pm 7.0$ & $146 \pm 6.3$ & 1000 \\
\hline $\mathrm{DOC}, \mathrm{mg} \mathrm{O}_{2} \mathrm{~L}^{-1}$ & $11.4 \pm 0.8$ & $8.8 \pm 0.9$ & $<4.0$ \\
\hline TURB, NTU & $36.2 \pm 2.4$ & $36.2 \pm 2.4$ & - \\
\hline Sal, $\mathrm{g} \mathrm{kg}^{-1}$ & $0.11 \pm 0.003$ & $0.11 \pm 0.003$ & - \\
\hline $\mathrm{Cl}^{-}, \mathrm{mg} \mathrm{L}^{-1}$ & $2.08 \pm 0.43$ & $2.23 \pm 0.46$ & 300 \\
\hline $\mathrm{SO}_{4}^{2-}, \mathrm{mg} \mathrm{L}^{-1}$ & $1.15 \pm 0.08$ & $1.03 \pm 0.07$ & 100 \\
\hline $\mathrm{HCO}^{3-}, \mathrm{mg} \mathrm{L}^{-1}$ & $136.64 \pm 3.15$ & $142.74 \pm 2.43$ & - \\
\hline $\mathrm{Na}^{+}, \mathrm{mg} \mathrm{L}^{-1}$ & $15.46 \pm 1.23$ & $16.65 \pm 0.99$ & 120 \\
\hline $\mathrm{K}^{+}, \mathrm{mg} \mathrm{L}^{-1}$ & $3.5 \pm 0.16$ & $3.6 \pm 0.19$ & 50 \\
\hline $\mathrm{Mg}^{2+}, \mathrm{mg} \mathrm{L}^{-1}$ & $7.04 \pm 0.55$ & $7.01 \pm 0.54$ & 40 \\
\hline $\mathrm{Ca}^{2+}, \mathrm{mg} \mathrm{L}^{-1}$ & $20.01 \pm 0.51$ & $21.01 \pm 0.56$ & 180 \\
\hline $\mathrm{Fe}, \mathrm{mg} \mathrm{L}^{-1}$ & $0.005 \pm 0.002$ & $0.019 \pm 0.013$ & 0.1 \\
\hline $\mathrm{Zn}, \mathrm{mg} \mathrm{L}^{-1}$ & $0.0007 \pm 0.0004$ & $0.0038 \pm 0.0023$ & 0.01 \\
\hline $\mathrm{Mn}, \mathrm{mg} \mathrm{L}^{-1}$ & $<0.001$ & $0.865 \pm 0.099$ & 0.01 \\
\hline $\mathrm{Pb}, \mathrm{mg} \mathrm{L}^{-1}$ & $<0.001$ & $0.0017 \pm 0.0005$ & 0.006 \\
\hline $\mathrm{Ni}, \mathrm{mg} \mathrm{L}^{-1}$ & $<0.001$ & $<0.001$ & 0.01 \\
\hline $\mathrm{Cd}, \mathrm{mg} \mathrm{L}^{-1}$ & $<00001$ & $<0.0001$ & 0.005 \\
\hline $\mathrm{Cr}, \mathrm{mg} \mathrm{L}^{-1}$ & $<0.001$ & $<0.001$ & 0.02 \\
\hline
\end{tabular}

3 Note: *MPC - the maximum permissible concentration for lakes fishery use in Russia (FAF, 4 2020). 
Table 4 (on next page)

Table 4. The concentration of nutrients (nitrogen and phosphorus) and organic matter content (OMC) in the central zone of the Lake Arakhley for the summer period 2017-2018 (mg L-1).

Note: PO - permanganate oxidability; COD - chemical oxygen demand 
1 Table 4. The concentration of nutrients (nitrogen and phosphorus) and organic matter

2 content (OMC) in the central zone of the Lake Arakhley for the summer period 2017-2018

$3\left(\mathrm{mg} \mathrm{L}^{-1}\right)$.

\begin{tabular}{|l|l|l|l|l|l|l|l|}
\hline \multirow{2}{*}{$\begin{array}{l}\text { Water } \\
\text { horizon }\end{array}$} & \multicolumn{2}{|l|}{ Nitrogen } & \multicolumn{2}{l|}{ Phosphorus } & \multicolumn{2}{l|}{ OMC } \\
\cline { 2 - 8 } & $\mathbf{N O}_{2}^{-}$ & $\mathbf{N O}_{\mathbf{3}^{-}}$ & $\mathbf{N H}_{4}{ }^{+}$ & $\mathbf{P O}_{4}{ }^{\mathbf{-}}$ & $\mathbf{P}_{\text {total }}$ & PO & COD \\
\hline $\begin{array}{l}\text { surface } \\
\text { layer (n=25) }\end{array}$ & 0.001 & 0.51 & 0.004 & 0.014 & 0.031 & 4.89 & 10.28 \\
\hline SD & 0.0001 & 0.048 & 0.0004 & 0.0013 & 0.0011 & 0.97 & 3.23 \\
\hline $\begin{array}{l}\text { bottom layer } \\
(\mathrm{n}=25)\end{array}$ & 0.006 & 0.56 & 0.002 & 0.023 & 0.038 & 6.1 & 12.43 \\
\hline SD & 0.0007 & 0.054 & 0.0002 & 0.0022 & 0.0022 & 6.2 & 4.1 \\
\hline
\end{tabular}

4 Note: $\mathrm{PO}$ - permanganate oxidability; COD - chemical oxygen demand 


\section{Table 5 (on next page)}

Table 5. Species composition of phytoplankton in the central part of Lake Arakhley 
1 Table 5. Species composition of phytoplankton in the central part of Lake Arakhley

\begin{tabular}{|c|c|c|c|c|c|c|c|c|c|}
\hline \multirow[b]{2}{*}{ No. } & \multirow[b]{2}{*}{ Taxa } & \multicolumn{4}{|c|}{2017} & \multicolumn{4}{|c|}{2018} \\
\hline & & 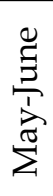 & 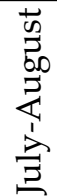 & $\begin{array}{l}\bar{D} \\
\overline{0} \\
\dot{0} \\
0\end{array}$ & 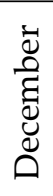 & 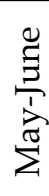 & 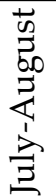 & $\begin{array}{l}\grave{\mathrm{U}} \\
\stackrel{0}{0} \\
\stackrel{0}{0}\end{array}$ & 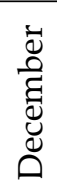 \\
\hline 1 & 2 & 3 & 4 & 5 & 6 & 7 & 8 & 9 & 10 \\
\hline & Cyanobacteria & & & & & & & & \\
\hline 1 & Gomphosphaeria lacustris Chodat, 1898 & + & - & + & + & - & + & - & + \\
\hline 2 & Anabaena sp. & + & - & + & - & - & - & - & \\
\hline 3 & $\begin{array}{l}\text { Aphanizomenon flos-aquae Ralfs ex Bornet \& } \\
\text { Flahault, } 1886\end{array}$ & + & - & + & - & + & - & + & - \\
\hline 4 & $\begin{array}{l}\text { Bacillariophyta } \\
\text { Lindavia comta (Kützing) Nakov, Gullory, Julius, } \\
\text { Theriot \& Alverson, } 2015\end{array}$ & + & + & + & + & + & + & + & + \\
\hline 5 & Melosira varians C.Agardh, 1827 & - & - & - & - & - & + & - & + \\
\hline 6 & Fragilaria crotonensis Kitton, 1869 & + & + & - & - & + & + & - & + \\
\hline 7 & F. radians (Kützing) D.M.Williams \& Round, 1987 & + & - & - & - & + & + & - & + \\
\hline 8 & $\begin{array}{l}\text { Ulnaria ulna (Nitzsch) Compère in Jahn et al., } \\
2001\end{array}$ & + & - & - & - & + & - & - & + \\
\hline 9 & Asterionella formosa Hassall, 1850 & - & + & + & - & - & + & + & + \\
\hline 10 & $\begin{array}{l}\text { Nitzschia graciliformis Lange-Bertalot \& Simonsen, } \\
1978\end{array}$ & + & - & + & - & - & - & - & - \\
\hline & Chrysophyta & & & & & & & & \\
\hline 11 & Chrysococcus rufescens Klebs, 1892 & + & + & - & + & - & - & - & + \\
\hline 12 & Dinobryon bavaricum Imhof, 1890 & + & - & - & - & + & - & - & + \\
\hline 13 & D. cylindricum O.E. Imhof, 1887 & + & - & - & - & + & - & - & + \\
\hline 14 & D. divergens O.E.Imhof, 1887 & + & + & + & - & + & - & + & + \\
\hline 15 & D. elegans Korshikov, 1926 & + & - & - & - & + & + & - & - \\
\hline 16 & D. sertularia Ehrenberg, 1834 & + & - & - & - & + & - & - & - \\
\hline 17 & $\begin{array}{c}\text { Kephyrion spirale (Lackey) Conrad, } 1939 \\
\text { Charophyta }\end{array}$ & + & - & - & - & + & - & - & + \\
\hline 18 & Elakatothrix genevensis (Reverdin) Hindák, 1962 & + & - & - & - & - & - & - & - \\
\hline 19 & Cosmarium sp. & - & + & - & + & - & + & + & + \\
\hline 20 & Staurastrum sp. & + & - & + & + & - & + & + & + \\
\hline 21 & $\begin{array}{l}\text { Chlorophyta } \\
\text { Mucidosphaerium pulchellum (H.C.Wood) C.Bock, } \\
\text { Proschold \& Krienitz, } 2011\end{array}$ & - & + & - & + & - & + & - & + \\
\hline 22 & Actinastrum hantzschii Lagerheim, 1882 & + & - & - & - & - & + & - & - \\
\hline 23 & Oocystis marssonii Lemmermann, 1898 & + & + & + & + & + & + & + & + \\
\hline 24 & O. borgei J.W.Snow, 1903 & - & + & + & + & - & + & - & + \\
\hline 25 & Lagerheimia genevensis (Chodat) Chodat 1895 & - & - & + & - & - & + & - & - \\
\hline 26 & Monoraphidium contortum (Thuret) Komárková- & + & - & - & - & + & + & - & - \\
\hline
\end{tabular}




\begin{tabular}{|c|c|c|c|c|c|c|c|c|c|}
\hline 27 & $\begin{array}{l}\text { Legnerová in Fott, } 1969 \\
\text { M. griffithii (Berkeley) Komárková-Legnerová, } \\
1969\end{array}$ & + & - & + & - & - & + & . & + \\
\hline 28 & M. komarkovae Nygaard, 1979 & + & - & + & - & - & + & & + \\
\hline 29 & Coelastrum microporum Nägeli in A.Braun, 1855 & - & - & + & - & - & - & & - \\
\hline 30 & Tetraëdron incus (Teiling) G.M.Smith, 1926 & + & + & - & - & + & - & & - \\
\hline 1 & 2 & 3 & 4 & 5 & 6 & 7 & 8 & & 10 \\
\hline 31 & T. minimum (A.Braun) Hansgirg, 1888 & - & - & + & + & + & - & & + \\
\hline 32 & $\begin{array}{l}\text { Pseudopediastrum boryanum (Turpin) E.Hegewald } \\
\text { in Buchheim et al., } 2005\end{array}$ & - & - & - & - & - & + & & + \\
\hline 33 & Schroederia setigera (Schröder) Lemmermann, 1898 & - & + & - & + & - & + & & + \\
\hline 34 & Chlamydomonas globosa J.W.Snow, 1903 & + & + & + & - & + & - & & - \\
\hline 35 & $\begin{array}{l}\text { Pandorina morum (O.F.Müller) Bory in } \\
\text { J.V.Lamouroux, Bory \& Deslongschamps, } 1824\end{array}$ & - & - & + & - & + & + & & - \\
\hline 36 & $\begin{array}{c}\text { Koliella longiseta (Vischer) Hindák, } 1963 \\
\text { Dinophyta }\end{array}$ & - & - & - & + & - & - & & + \\
\hline 37 & Ceratium hirundinella (O.F.Müller) Dujardin, 1841 & - & + & - & - & - & + & & - \\
\hline 38 & $\begin{array}{l}\text { Peridinium sp. } \quad \text { Euglenophyta } \\
\end{array}$ & + & + & - & - & + & + & & - \\
\hline 39 & Trachelomonas sp. & + & - & - & - & + & - & & - \\
\hline
\end{tabular}

2 


\section{Table 6(on next page)}

Table 6. Dominant phytoplankton complex and average per year biomass in the Lake Arakhley in different at different periods of study

Note: ${ }^{1-4}$ - at Morozova $(1975,1981) ;{ }^{5-6}$ - at Morozova \& Shishkin (1973); Morozova (1981); ${ }^{7-8}$

- at Ogly $(1993,1995) ;{ }^{10-11}$ - at Tashlykova \& Koryakina (2013) 


\begin{tabular}{|c|c|c|c|c|c|c|c|c|c|c|c|c|}
\hline \multirow{2}{*}{$\begin{array}{c}\text { Paramete } \\
\text { r }\end{array}$} & \multicolumn{12}{|c|}{ Research year } \\
\hline & $\begin{array}{c}1966 \\
1\end{array}$ & $\begin{array}{c}1967 \\
2\end{array}$ & $\begin{array}{c}196 \\
8^{3}\end{array}$ & $\begin{array}{c}1969 \\
4\end{array}$ & $1970^{5}$ & $1971^{6}$ & $1988^{7}$ & $\begin{array}{c}199 \\
4^{8}\end{array}$ & $\begin{array}{c}199 \\
5^{9}\end{array}$ & $2008^{10}$ & $2009^{11}$ & 2017-2018 \\
\hline 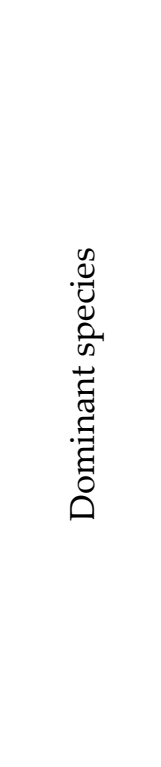 & $\begin{array}{r}M \\
H \\
C \\
\text { seti } \\
\text { pseud }\end{array}$ & $\begin{array}{l}\text { yclotel } \\
\text { crocyst } \\
\text { lopedia } \\
\text { troomo } \\
\text { Schro } \\
\text { era;Ant } \\
\text { mirabil } \\
\text { Ooc }\end{array}$ & $\begin{array}{l}\text { comto } \\
\text { pulve } \\
\text { gemina } \\
\text { as acut } \\
\text { deria } \\
\text { strodes } \\
\text {; видь } \\
\text { stis }\end{array}$ & $\begin{array}{l}\text { ea; } \\
\text { a; } \\
\text {; } \\
\text { тия } \\
\text { рода }\end{array}$ & $\begin{array}{r}\text { Asterion } \\
\text { Microcy } \\
\text { Holoped } \\
\text { Chroom } \\
\text { Sch } \\
\text { setigera; } A \\
\text { s pseudon } \\
\text { poda }\end{array}$ & $\begin{array}{l}\text { formosa; } \\
\text { pulverea; } \\
\text { eminata; } \\
\text { s acuta; } \\
\text { eria } \\
\text { trodesmu } \\
\text { ilis; вudbl } \\
\text { ystis }\end{array}$ & $\begin{array}{l}\text { Asterionella } \\
\text { formosa; } \\
\text { Microcystis } \\
\text { pulverea; } \\
\text { Anabaena } \\
\text { spiroides; } \\
\text { Aulacoseira } \\
\text { granulata; } \\
\text { Fragilaria } \\
\text { crotonensis }\end{array}$ & $\begin{array}{l}\text { Gloed } \\
\text { echir } \\
\text { Aster } \\
\text { for } \\
\text { Auld } \\
\text { grar }\end{array}$ & $\begin{array}{l}\text { richia } \\
\text { ılata; } \\
\text { onella } \\
\text { osa; } \\
\text { osira } \\
\text { ılata }\end{array}$ & $\begin{array}{c}\text { Cyclotella } \\
\text { comta; } \\
\text { Asterionella } \\
\text { formosa; } \\
\text { Melosira } \\
\text { varians; } \\
\text { виды рода } \\
\text { Dinobryon; } \\
\text { Ceratium } \\
\text { hirundinella; } \\
\text { Tetraëdron } \\
\text { incus }\end{array}$ & $\begin{array}{c}\text { Cyclotella } \\
\text { comta;Chromulina } \\
\text { sp.; Asterionella } \\
\text { formosa; Ceratium } \\
\text { hirundinella; } \\
\text { Gloeotrichia } \\
\text { echinulata; вudb } \\
\text { poda Dinobryon }\end{array}$ & $\begin{array}{c}\text { Lindavia } \\
\text { comta }=\text { Cyclotella } \\
\text { comta, Fragilaria } \\
\text { crotonensis, F. } \\
\text { radians, Ulnaria } \\
\text { ulna, Nitzschia } \\
\text { graciliformis, } \\
\text { Chrysococcus } \\
\text { rufescens, } \\
\text { Dinobryon } \\
\text { cylindricum, D. } \\
\text { divergens, D. } \\
\text { sertularia, } \\
\text { Kephyrion } \\
\text { spirale,Oocystis } \\
\text { marssonii }\end{array}$ \\
\hline $\begin{array}{l}\text { Biomass } \\
\text { (average } \\
\text { per year, } \\
\text { in } \mathrm{g}^{*} \mathrm{~m}^{-3} \text { ) }\end{array}$ & $\begin{array}{c}1,35 \\
6\end{array}$ & $\begin{array}{c}0,55 \\
7\end{array}$ & 0,21 & $\begin{array}{c}0,36 \\
6\end{array}$ & 0,245 & 0,2 & 0,69 & 61 & 26,4 & 1,5 & 2,5 & $0,94-1,1$ \\
\hline
\end{tabular}

Note: ${ }^{1-4}$ - at Morozova $(1975,1981) ;{ }^{5-6}$ - at Morozova \& Shishkin (1973); Morozova (1981); ${ }^{7-8}-$ at Ogly $(1993,1995) ;{ }^{10-11}-$ at Tashlykova \& Koryakina (2013) 